DOI 10.22460/infinity.v6i1.234

\title{
DEVELOPING STUDENTS' ABILITY OF MATHEMATICAL CONNECTION THROUGH USING OUTDOOR MATHEMATICS LEARNING
}

\author{
Saleh Haji ${ }^{1}$, M. Ilham Abdullah ${ }^{2}$, Syafdi Maizora $^{3}$, Yumiati ${ }^{4}$ \\ ${ }^{1,2,3}$ Department of Mathematics Education Bengkulu University, Bengkulu, Indonesia \\ ${ }^{4}$ Department of Mathematics Education Open University, Indonesia \\ ${ }^{1}$ salehhaji25@gmail.com, ${ }^{2}$ ilhamabdullah418@gmail.com, ${ }^{3}$ syafdiiemaizora@yahoo.com, \\ 4yumiatis@gmail.com
}

Received: October 20, 2016; Accepted: November 12, 2016

\begin{abstract}
The Purpose of this study is to determine the achievement and improvement of students' mathematical connectionability through using outdoor mathematics learning. 64 students from the fifth grade of Primary School at SDN 65 and SDN 67 Bengkulu City were taken as the sample of this study. While the method of the research used in this research is experiment with quasi-experimental designs nonequivalent control group. The results of the study are as follows: (1) There is an increasing ability found in mathematical connection of students whom taught by using outdoors mathematics learning is 0,53 ; (2) Based on statical computation that achievement of students' ability of mathematical connection is taught by using outdoor mathematics learning score is 71,25. It is higher than the students score 66,25 which were taught by using the conventional learning. So as to improve students' mathematical connection, teachers are suggested to use the outdoors mathematics learning.
\end{abstract}

Keywords: mathematical connection ability, outdoor mathematics learning

\begin{abstract}
Abstrak
Tujuan penelitian ini adalah untuk menentukan pencapaian dan peningkatan kemampuan koneksi matematika siswa melalui pembelajaran matematika di luar ruangan. Sampel dalam penelitian ini sebanyak 64 orang siswa yang berasal dari kelas lima sekolah dasar pada SDN 65 dan SDN 67 Kota Bengkulu. Metode yang digunakan adalah eksperimen dengan desain kuasi-eksperimental nonquivalen kelompok kontrol. Hasil dari penelitian ini adalah sebagai berikut: (1) terdapat peningkatan kemampuan koneksi matematis siswa yang belajar di luar ruangan, dengan peningkatan sebesar 0.53. (2) pencapaian kemampuan koneksi matematis siswa yang belajar di luar ruangan (71.25) lebih tinggi daripada siswa yang belajar dengan cara convensional (66.25). Sehingga untuk meningkatkan kemampuan koneksi matematis siswa, hendaknya guru dapat melakukan pembelajaran matematika di luar ruangan.
\end{abstract}

Kata Kunci: model pembelajaran penemuan terbimbing, pemahaman konsep kalkulus integral

How to Cite: Haji, S., Abdullah, M. I., Maizora, S. \& Yumiati (2017). Developing Students' Ability of Mathematical Connection Through Using Outdoor Mathematics Learning. Infinity, 6 (1), 11-20.

\section{INTRODUCTION}

Generally, primary schools in Indonesia organized learning in the classroom. Learning in the classroom has many weaknesses in instilling mathematical concepts to students. The weaknesses among other things, teachers are not flexible in linking the mathematical concepts 
to everyday life. Similarly, students are limited in observing the real objects of everyday life are related to mathematics. This led to the ability of understanding mathematical concepts, especially the ability of mathematical connection students do not develop properly.

Mathematical connection capability is one capability that suggested by the NCTM. According to the NCTM (1989), mathematics skills need to be developed through the study of mathematics as follows: 1. Problem solving, 2. Reasoning and Proof, 3. Communication, 4. Connection, and 5. Representation.

Mathematical connection capability is the ability of students in linking the various issues related to mathematics. The connectionis included in mathematics and between mathematics with things outside mathematics. As link the concepts included in Algebra with the concepts included in Geometry. The linking of mathematics to other disciplines and to everyday life.

Connection between mathematics and outside mathematics should be developed through the study of mathematics. Because mathematics is a science that includes a lot of the linking between concept.As the link between the concept of relationship with the concept of function.The linking of the addition operation with multiplication operations on numbers. The linking of the concept of the derivative function with the concept of profit and loss in the economic field.As well as the linking of the concept of the exponential growth of bacteria.

To improve students' mathematical connection required learning related to everyday life. Learning that includes such properties are learning outside the classroom (outdoor education). Kennard (2007) link the recreational ride trains children with their understanding of numbers. Moffett (2010) describes the things are interlinked in a museum. Like other forms of geometry contained in ancient objects.

Results of research Daher and Bayaa (2011) found that cell phone use can increase students' understanding of mathematical objects. While Burriss and Burris (2011) found that learning outside the classroom through game activities can improve students' ability to solve a problem.

The problems of this study as follows:

1. Is there an increase in the ability of mathematical connection students taught through outdoor learning mathematics?

2. Is the achievement ofstudents mathematical connectiontaught through outdoor learning mathematics is higher than those taught by conventional teaching?

\section{Mathematical Connections Ability}

Mathematical connection ability is the ability of linking between components in mathematics, the mathematics to other disciplines, and between mathematics to everyday life. Kutz in Yusepa (2002) states that the mathematical connection includes internal and external relationships mathematically.Mathematical knowledge about organized structure (Ruseffendi, 1991). Organizations in mathematics linking the various elements contained therein. The elements in mathematics may consist of: Algebra, Geometry, Arithmetic, Probability, and Calculus. In addition, the mathematics may also consist of facts, concepts, principles, and skills. As the link between the concept of a square with a parallelogram. The square is a parallelogram that all sides are equal in length and all the right-angled corners. Kusuma (2003), classifies the mathematical connections consist of: 1 . The connections between topics 
and mathematical processes, 2 . Connections between mathematics with other sciences, and 3 . Connections between mathematical concepts to everyday life.

The linkage between concepts in mathematics and between mathematics to everyday life can help students understand mathematical concepts. As to understand the concept of integer multiplication through its association with the concept of the sum of the integers.Because the integer multiplication is repeated addition of integers. Fisher in Ruspiani (2000) mentions that the mathematical connection was an attempt to foster students' understanding.

Sumarmo (2000) describes the importance of mathematics connection ability in mathematics, namely: 1. Expanding horizons, 2. Clarify mathematics as a whole, and 3. Clarify the benefits of mathematics.

\section{The Outdoor Learning in Mathematics}

The outdoor learning in mathematics is mathematics that relies on learning activities outside the classroom. It focuses on the learning activities of students and teachers outside the classroom. The places of classroomoutside, such as: the school yard, garden, market, health hospital, police offices and others. Husamah (2013) explains an outdoor learning outside of school activities that contain activities outside the classroom and the other in the wild. Amin (2008) explains that the method of outdoorlearning process is a method of learning science by doing adventure in the neighborhood, accompanied by thorough observation that the results recorded in the observation worksheets. According to Bartlet in Husamah (2013), an outdoor education learning model is a learning outside the room or outside the classroom.

Activities outside the classroom as an environment for children to learn mathematics. Real and dynamic environment that can facilitate the child understand the mathematics material. Bratton (2005) explains that learning mathematics outdoors provides an environment for children to learn.

Maizora \& Haji (2015) describe the steps of outdoor mathematics as follows:

1. Teachers prepare students to be ready to follow the lesson.

2. Teachers express purpose of learning.

3. Teacher conveys exactly the material to be learned and how learning will be done outside the classroom.

4. Teachers encourage students out of the classroom to the place (an object) that is associated with mathematics. The objects can be objects, phenomena, or form of the game.

5. Students observe and manipulate these objects or perform a play.

6. Teachers guide students to discuss the mathematical concepts contained in the object being observed or in a game they do.

7. Teachers together students concluded various mathematical concepts contained in the objects and the game were done.

8. Teachers invite students back into the classroom.

9. Teachers clarify and review the mathematical concepts that have been obtained by the students outside the classroom and to associate with learning objectives (competencies) to be achieved.

10. The teacher presents a summary of the lessons that have been done together students. 
11. Teachers assign tasks to students to solidify understanding of the concepts they have learned and provide direction on the material to be studied and activities outside the classroom at the next meeting.

\section{METHOD}

\section{Type of Research}

This research is a quasi-experimental design with a nonrandomized control group, pretestposttest design, the following:

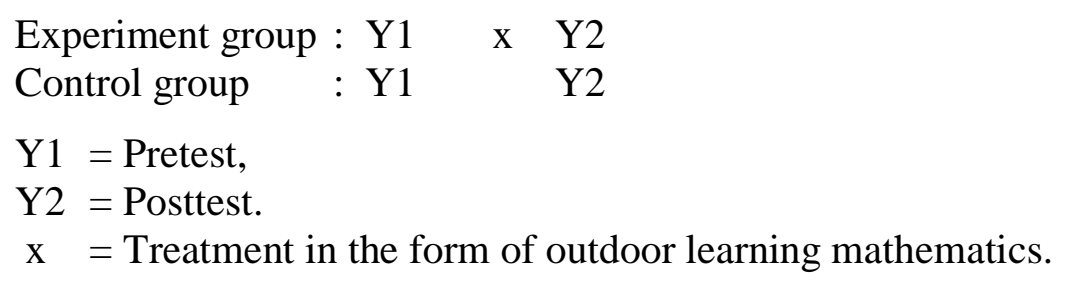

\section{Sample and Population}

These students study population are of State ElementarySchool 67 Bengkulu City. While the study sample is grade 5 at State Elementary School 67 Bengkulu City. Sampling is done purposefully

\section{Instrument Reseach and Development}

The instrument of this research is questions about the ability of mathematical connections on the topic Operation Count on Integer. On the essay form as much as four grains. The trial results and analysis, obtained a set of questions about the mathematical connections that are valid and reliable. The results of the analysis instrument by using SPSS 12 (Trihendradi, 2004) is presented in Table 1 below.

Table 1.Development of Research Instruments

\begin{tabular}{clc}
\hline No. & \multicolumn{1}{c}{ Variables } & Result \\
\hline 1 & Average Score & 66,00 \\
2 & Standard Deviation & 10,01 \\
3 & Correlation XY & 0,62 \\
4 & Reliability Test & 0,76 \\
5 & Items & 4 \\
6 & Validity Item 1 & 0,79 \\
7 & Validity Item 2 & 0,75 \\
8 & Validity Item 3 & 0,80 \\
9 & Validity Item 4 & 0,71 \\
10 & Number of Subjects & 40 \\
\hline
\end{tabular}

Results judging of grains instruments by three experts in the field of mathematics education show that they give the same rating to the four-point test that can be used to measure the ability of mathematical connections, after some repairs. 
The research was conducted at Mathematics Education, Teacher Training and Education Faculty, Widya Dharma University, Klaten. The research was quasy experimental research because only some of relevant variables that were controlled or manipulated.The sample was the students of Mathematics Education in even semester who took integral calculus subject with the use of certain integral in accomplishing a problem as the material. Cluster random sampling was implemented to find out a representative sample of the population. Based on the result of cluster random sampling, the control group that was taught using Conventional model consisted of 22 students meanwhile the experimental group that was taught using Guided Discovery Learning consisted of 34 students.

\section{Data Analysis}

Data about upgrading mathematical connections were analyzed by using N-Gein. While data on the achievement of mathematical connection capabilities were analyzed using t-test when the data were normally distributed. When the data are not normally distributed, the MannWhitney test was used.

\section{RESULTS AND DISCUSSION}

\section{Achieving the ability to mathematical connection students taught through outdoor learning mathematics}

The test results of pretest and posttest data normality on a mathematical connection capability acquired rejection by Ho which means each pretest and posttest data is not normal. This is shown in Table 2 and Table 3. Similarly to the data of N-Gein, is not normal. This is shown in Table 2.

Table 2. Results of Normality Pretest Data of Mathematical Connection

\begin{tabular}{|c|c|c|c|c|c|c|}
\hline Data Group & $N$ & Average & $\begin{array}{l}\text { Dev. } \\
\text { Stand. }\end{array}$ & $\begin{array}{c}\text { Kolmogoro } \\
\text { v-Smirnov } \\
Z\end{array}$ & $\begin{array}{c}\text { Sig. } \\
(2- \\
\text { way) }\end{array}$ & $\mathbf{H}_{\mathbf{0}}$ \\
\hline $\begin{array}{l}\text { Pretest of experimental } \\
\text { group }\end{array}$ & 40 & 34,25 & 19,20 & 0,172 & 0,004 & Rejection \\
\hline Pretest of Control Group & 40 & 33,50 & 15,94 & 0,158 & 0,013 & Rejection \\
\hline
\end{tabular}

Based on Table 2, the data pretest mathematical connection capabilities in both sets of data are not normally distributed. Therefore, to know the difference between the two groups, namely learning mathematics outdoor learning and conventional learning Mann-Whitney test was used.

Mann-Whitney test to pretest the data connection capabilities of the experimental group and the control group revenue generating Ho, so no significant differences prior knowledge mathematical connection between the experimental group and the group control. So initial capabilities of the two groups are the same. This is shown in Table 3. 
Table 3. Results of Mann-Whitney Test of Mathematical Connection Abilty

\begin{tabular}{cccccc}
\hline Data Group & Average & $\begin{array}{c}\boldsymbol{U} \\
\text { Mann Whitney }\end{array}$ & $\boldsymbol{Z}$ & $\begin{array}{c}\text { Sig.(2- } \\
\text { way) }\end{array}$ & $\mathbf{H}_{\mathbf{0}}$ \\
\hline $\begin{array}{c}\text { Pretest of experimental } \\
\text { group }\end{array}$ & 34,25 & 770,500 & $-0,289$ & 0,772 & Accepted \\
$\begin{array}{c}\text { Pretest of Control Group } \\
\text { Prot }\end{array}$ & 33,50 & & & & \\
\hline
\end{tabular}

The data normality test results posttes mathematical connection capabilities of the two groups using the Kolmogorov-Semirnov indicate that Ho is accepted. This means, the two groups are not normally distributed. This is shown in Table 4. Therefore, different test for two groups using the Mann-Whitney test.

Table 4. Results Normality Test Data of Mathematical Connection Ability

\begin{tabular}{ccccccc}
\hline Data Group & $\boldsymbol{N}$ & Average & $\begin{array}{c}\text { Dev. } \\
\text { Stand. }\end{array}$ & $\begin{array}{c}\text { Kolmogorov- } \\
\text { Smirnov } Z\end{array}$ & $\begin{array}{c}\text { Sig. } \\
\text { way) }\end{array}$ & $\mathbf{H}_{\mathbf{0}}$ \\
\hline $\begin{array}{c}\text { Posttest of } \\
\text { experimental group }\end{array}$ & 40 & 71,25 & 6,96 & 0,354 & 0,00 & Rejection \\
$\begin{array}{c}\text { Posttest of Control } \\
\text { Group }\end{array}$ & 40 & 66,25 & 9,66 & 0,216 & 0,00 & Rejection \\
\hline
\end{tabular}

Test of differences achievement the students'ability aboutmathematicalconnection atthe experimental group with the control group using the Mann-Whitney Ho generates revenue. This means that there are differences in achievement ability mathematical connection between the experimental group and control group. This is shown in Table 5. The mean scores of mathematical connection ability of the experimental group 71.25 greater than the mathematical connection ability control group students at 66.25. This means, the achievement of mathematical connection ability of students taught using the outdoor mathematics better than students taught using conventional learning.

Table 5. Calculation Results Mann-Whitney Postest of Mathematical Connection Ability

\begin{tabular}{cccccc}
\hline Data Group & Average & $\begin{array}{c}\boldsymbol{U} \\
\text { Mann Whitney }\end{array}$ & $\boldsymbol{Z}$ & sig.(1-way) & $\mathbf{H}_{\mathbf{0}}$ \\
\hline $\begin{array}{c}\text { Postest of } \\
\text { Experimental Group }\end{array}$ & 71,25 & & & & \\
$\begin{array}{c}\text { Postest of Control } \\
\text { Group }\end{array}$ & 66,25 & 505,000 & - & 0,0015 & Rejection \\
\hline
\end{tabular}

Students are taught through through outdoor learning mathematics can link between mathematics and the mathematics section with everyday life. Such as linking the relationship between the number 10 to number 5. This relationship is as follows (Maizora \& Haji, 2015):
a. $10=5 \times 2$
b. $10=2 \times 5$
c. $10=15-5$
d. $10=5+5$ 
e. 10 is greater than 5 .

f. 5 is smaller than 10 .

g. $10=50: 5$

As many as $83 \%$ of students correctly answered questions about the relevance of the number 10 to number 5 . The ability of the student connection because the influence of outdoor learning mathematics that has provided the opportunity for students in linking various objects in everyday life. Students relate the number of marbles with numbers and a game of marbles with operations in a game of marbles. Purwanto (2008), outdoor learning can bring learners with learning objects. The real learning objects as a context for helping students understand mathematical connections. Nuriadin (2015) explains that there are differences in the students ability in mathematical connection taught through contextual learning with conventional. Beside, Martin, Falk, and Balling (1981) explain learning by a field trip to a novel setting is a better understanding of the details and nature of the cognition. In this case the game of marbles with the concept of numbers and their operations. This is shown in Figure 1 below.

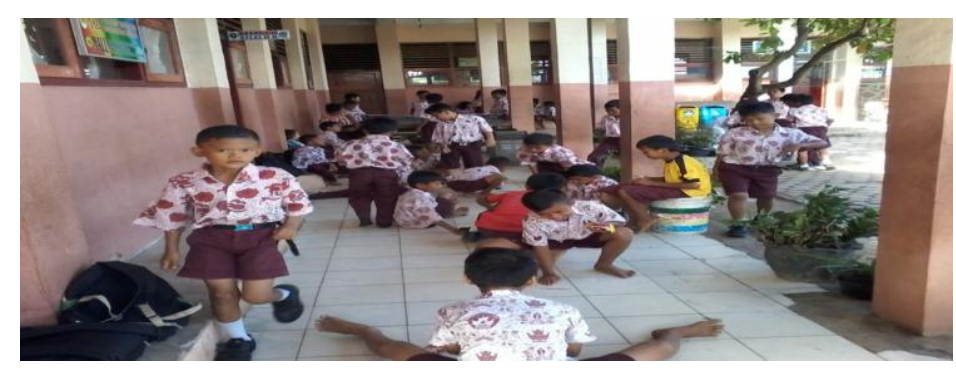

Figure 1. The students were playing marbles outside the classroom

When students learn about the topic Operation Count on Integer in the 'Sunday Market' in Bengkulu. Students relate between buyers and sellers. Seller is a person who sold the goods to the buyer. While the buyer is a person who buys goods from a seller. Similarly, students link the bananas and oranges. Students explain the link between bananas and oranges through color. Students say that the color of bananas and oranges at the yellow.

As many as $47 \%$ of students who answered questions correctly about the link between the number 10 to number 5 . A total of $53 \%$ of students taught by conventional teaching experience difficulties in linking between the number 10 to number 5 . According to them, number 10 with number 5 are two different numbers, so it cannot be associated with each other.

Achievement of mathematical connection abilityin both groups shown in Figure 2 below. 


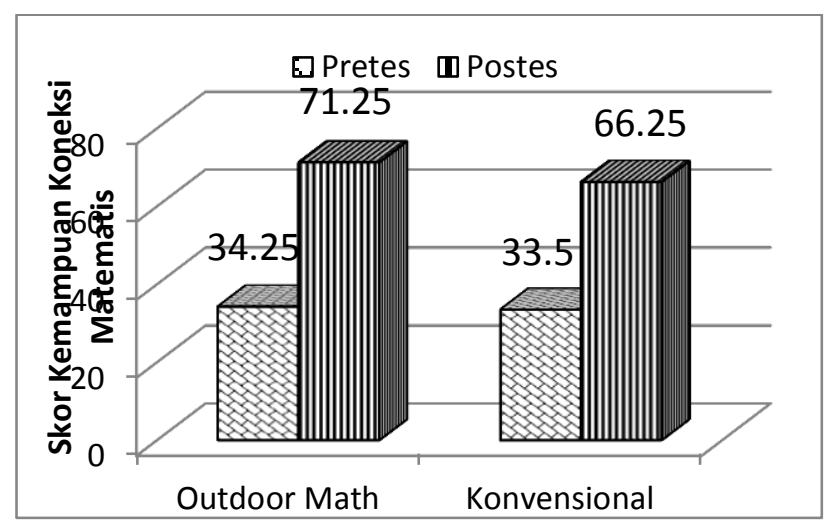

Figure 2. Achievement of Students Ability of Mathematical Connections Through the Outdoor Learning Mathematics

\section{To increase the students' ability ofmathematical connection taught through outdoor learning mathematics}

Results of data normality test N-Gain mathematical connection capabilities by using the Kolmogorov-Smirnov obtained rejection of Ho. This means, the two groups are not normally distributed. This is shown in Table 6 below.

Table 6. Results Normality Test Data Connection N-gain Mathematical Ability

\begin{tabular}{lcccccc}
\hline \multicolumn{1}{c}{ Data Group } & $\boldsymbol{N}$ & Average & $\begin{array}{c}\text { Dev. } \\
\text { Stand. }\end{array}$ & $\begin{array}{c}\text { Kolmogorov- } \\
\text { Smirnov } \boldsymbol{Z}\end{array}$ & $\begin{array}{c}\text { Sig. } \\
\mathbf{2}-\end{array}$ & $\mathbf{H}_{\mathbf{0}}$ \\
\hline $\begin{array}{l}\text { Nay) } \\
\text { Group Eksperimental }\end{array}$ & 40 & 0,53 & 0,17 & 0,158 & 0,014 & Rejection \\
$\begin{array}{l}\text { N-gain Control } \\
\text { Group }\end{array}$ & 40 & 0,46 & 0,20 & 0,145 & 0,034 & Rejection \\
\end{tabular}

Different test improvement (N-Gain) mathematical connection capability in both groups using the Mann-Whitney Ho generate revenue. This means, by enhancing the mathematical connections of students taught using the outdoor learning mathematics is no different with students taught using conventional learning. This is shown in Table 7 below.

Table 7. Calculation Results Mann-Whitney N-gain of Mathematical Connections Ability

\begin{tabular}{lccccc}
\multicolumn{1}{c}{ Data Group } & Average & $\begin{array}{c}\boldsymbol{U} \\
\text { Mann Whitney }\end{array}$ & $\boldsymbol{Z}$ & sig.(1-way) & $\mathbf{H}_{\mathbf{0}}$ \\
\hline $\begin{array}{l}\text { N-gain of Eksperimental } \\
\text { Group }\end{array}$ & 0,53 & & & & \\
N-gain of Control Group & 0,46 & 652,500 & $-1,424$ & 0,078 & Received \\
\hline
\end{tabular}

The magnitude of the increase in the ability students of mathematical connection taught using the outdoor learning mathematics 0.53 greater than the increase in the ability students of mathematical connection taught using the conventional learning 0.46. Despite an increase in 
the mathematical connectionability to the two groups did not differ significantly. This is because the outdoor learning makes students more excited in learning mathematics, thereby increasing their interest in mathematics. Widayanti (2003) explains that the method of outdoor study successfully increased student interest.

Such improvements in terms of linking between sections of mathematics and mathematics relate to everyday life. Such as linking between the number of patients treated at the hospital Dr. M. Yunus Bengkulu as a summation and the number of patients who return stay overnight as a reduction on outdoor learning mathematics with the theme 'Inpatient Hospital of Dr. M. Yunus Bengkulu '.

Improving the mathematical connection ability in the two study groups are presented in Figure 3 below.

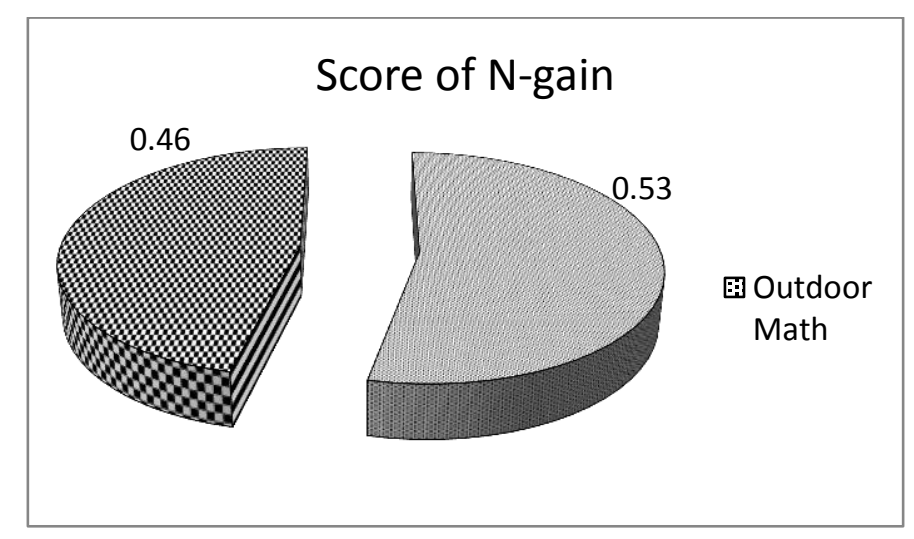

Figure 3. Upgrades Mathematical Connections students Through the Outdoor Learning Mathematics

\section{CONCLUSION}

1. Based on the statistical computation result of the data analysis found a score 0,53 . It means that mathematical connections whinch taugh outdoor learning is increased significantly.

2. Acievement of the students' ability of mathematical connection taught through outdoor mathematics learning is significantly greater than the students whom taught by using conventional learning. The score of data analysis computation result for out door learning at experimental group is 71.25 , while the attainment score found through the conventional learning method at the control group is 66.25.

\section{REFERENCES}

Amin, C. (2008). Memupuk Tradisi Ilmiah Siswa Sekolah Dasar Menggunakan Metode Outdoor Learning Process. Simposium Tahunan Penelitian.

Brattorn, C. (2005). Learning Outdoors. NSA Publication.

Burriss, K., \& Burris, L. (2011). Outdoor Play and Learning: Policy and Practice. International Journal of Education Policy and Leadership, 6(8), 78-89.

Daher, W., \& Bayaa, N. (2011). Characteristics of Middle School Students Learning Actions in Outdoor Mathematical Activites with The Celluler Phone. Oxford University Press. 
Husumah. (2013). Pembelajaran Luar Kelas Outdoor Learning. Jakarta: Prestasi Pustaka.

Kennard, J. (2007). Outdoor Mathematics. Mathematics Teaching Incorporating Micromath, 201, 16-18.

Kusuma, D. (2003). Meningkatkan Kemampuan Koneksi Matematik Siswa Sekolah Lanjutan Tingkat Pertama dengan Menggunakan Metode Inkuiri. Program Pascasarjana UPI. Bandung: Not Published.

Maizora, S., \& Haji, S. (2015). Model Pembelajaran Outdoor Mathematics Untuk Meningkatkan Kemampuan Koneksi dan Komunikasi Matematis Siswa Sekolah Dasar. LPPM Universitas Bengkulu. Bengkulu: Not Published.

Martin, W., Falk, J., \& Balling, J. (1981). Enviromental Effecs On Learning: The Outdoor Field Trip. Science Education, 65(3), 301-309.

Moffett, P. (2010). Back in Time on a Mathematics Trail. Mathematics Teaching, 219, 31-33.

NCTM. (1989). Curriculum and Evaluation Standards for School Mathematics. USA: The National Council of Teachers of Mathematics Inc.

Nuriadin, I. (2015). Pembelajaran Kontekstual Berbantuan Program Geometer's Sketchpad Dalam Meningkatkan Kemampuan Koneksi Dan Komunikasi Matematis Siswa SMP. Infinity Journal, 4(2), 168. doi:10.22460/infinity.v4i2.80.

Purwanto. (2008). Penerapan Metode Partisipatori Untuk Meningkatkan Keterampilan Menulis Puisi Siswa Kelas V Melalui Pembelajaran di Luar Kelas. Retrieved January 5, 2011, from http://purwanto65.wordpress.com

Ruseffendi, E. (1991). Pengantar kepada Membantu Guru Mengembangkan Kompetensinya dalam Pengejaran Matematika untuk Meningkatkan CBSA. Bandung: Tarsito.

Ruspiani. (2000). Kemampuan Siswa dalam Melakukan Koneksi Matematika. FPS UPI. Bandung: Not Published.

Sumarmo, U. (2000). Proses Belajar dan Pemahaman Materi Kuliah. Lokakarya TPB. Bandung: ITB.

Trihendradi, C. (2004). Memecahkan Kasus Statistik: Deskriptif, Parametrik, dan NonParametrik. Yogyakarta: Penerbit ANDI.

Widayanti, N. (2003). Efektivitas Pembelajaran Geografi Melalui Metode Outdoor Study dalam Upaya Meningkatkan Minat Belajar Siswa. Buletin Pelangi, 6(1), 125-134.

Yusepa, B. (2002). Penerapan Model Cooperative Learning Tipe Student-Team Achievement Divisions (STAD) dalam Upaya Meningkatkan Kemampuan Koneksi Matematika Siswa. UPI. Bandung: Not Published. 